\title{
Does Micropractice Lead to Macrosatisfaction?
}

\author{
Elizabeth Paddock, MD, Ronald J. Prince, MS, Meaghan Combs, MD, MPH, and \\ Melissa Stiles, MD
}

Background: Physician quality of work life is a key factor in career choice, satisfaction, and retention. The majority of physicians are currently employed by large health care organizations where physician loss of autonomy is common, yet some physicians have opened micropractices. There have been no previous studies comparing physician satisfaction between employed physicians and micropractice physicians.

Methods: A previously validated survey of physician satisfaction was sent to 72 physicians practicing in a residency setting, 111 physicians in community, nonresidency setting, and 42 physicians in a micropractice setting.

Results: Physicians in micropractices had the lowest satisfaction with income, but the highest satisfaction with family time and the ability to provide continuity of care. Micropractice physicians rated the overall quality of medical care they provide higher than employed physicians. Micropractice physicians reported a much smaller scope of practice.

Conclusions: Overall, physicians in micropractices found more satisfaction in their work at the cost of decreased income and a narrower scope of practice. (J Am Board Fam Med 2013;26:525-528.)

Keywords: Medical Practice Management, Work Satisfaction

Physician career satisfaction is low when there is a lack of control over the practice environment and increased perceived work demands. ${ }^{1}$ Since the 1950 s, many physicians have left solo practice for larger health care organizations, with decreased satisfaction. ${ }^{2}$ Some physicians strive to achieve a practice with longer office visits, limited paperwork, and higher satisfaction using the micropractice model. ${ }^{3}$ Micropractice physicians are independent practitioners who have low overhead, allowing for extended visit time with patients. ${ }^{4}$ In our review of the literature, there were no studies comparing physician satisfaction between the micropractice model and larger practices. The purpose of our study was to examine this comparison.

This article was externally peer reviewed.

Submitted 11 October 2012; revised 4 April 2013; accepted 23 April 2013.

From the Department of Family Medicine, University of Wisconsin, Madison.

Funding: none.

Conflict of interest: none declared.

Corresponding author: Elizabeth Paddock, MD, Partnership Health Center, 323 W. Alder St., Missoula, MT 59802 (E-mail: paddocke@phc.missoula.mt.us).

\section{Methods \\ Subjects}

Physicians in the family medicine department at a large midwestern university, including 72 residency faculty physicians (RPs) and 111 community physicians (CPs) in nonresidency clinics as well as a national group of 42 micropractice physicians (MPs) were invited to take the online survey. Resident physicians were excluded. No other inclusion or exclusion criteria were applied.

\section{Survey}

The survey had 13 content questions in 3 categories (work satisfaction, practice issues, outcomes). Other questions asked about practice setting (rural, urban, suburban); 4 asked about the scope of practice. The 13 content questions came from a previously validated survey. ${ }^{5}$ Following the block of questions in each of the above categories was a space for open-ended comments.

\section{Data Analysis}

We used the $\chi^{2}$ test for nominal items and the Kruskal-Wallis test for ordinal scale items. We created a composite satisfaction score by adding the 


\begin{tabular}{|c|c|c|c|c|c|}
\hline & \multirow[b]{2}{*}{ Likert Ratings } & \multicolumn{3}{|c|}{ Settings } & \multirow[b]{2}{*}{$P$ value } \\
\hline & & Community & Micropractice & Residency & \\
\hline \multicolumn{6}{|l|}{ Work satisfaction } \\
\hline How satisfied are you with your current income? & $\begin{array}{l}1=\text { not satisfied, } 5=\text { very } \\
\text { satisfied }\end{array}$ & $2.76(0.49)$ & $2.32(0.58)$ & $3.21(0.36)$ & 0.38 \\
\hline $\begin{array}{l}\text { How satisfied are you with the amount of family } \\
\text { time you have? }\end{array}$ & $\begin{array}{l}1=\text { not satisfied, } 5=\text { very } \\
\text { satisfied }\end{array}$ & $2.97(0.44$ & $4.09(0.45)$ & $2.34(0.32)$ & $<.001^{*}$ \\
\hline $\begin{array}{l}\text { How would you rate the quality of the working } \\
\text { relationships among physicians in your work } \\
\text { group? }\end{array}$ & $1=$ poor, $5=$ excellent & $3.79(0.43)$ & $4.39(0.42)$ & $3.97(0.33)$ & .099 \\
\hline $\begin{array}{l}\text { How satisfied are you with your ability to } \\
\text { provide continuity of care? }\end{array}$ & $\begin{array}{l}1=\text { not satisfied, } 5=\text { very } \\
\text { satisfied }\end{array}$ & $3.45(0.44)$ & $4.50(0.46)$ & $3.50(0.33)$ & $<.001^{*}$ \\
\hline \multicolumn{6}{|l|}{ Practice issues } \\
\hline How often do you work under time pressure? & $1=$ never, 5 = always & $4.07(0.31)$ & $2.50(0.42)$ & $4.05(0.21)$ & $<.001^{*}$ \\
\hline $\begin{array}{l}\text { Do you agree or disagree that the amount of } \\
\text { paperwork you process is reasonable? }\end{array}$ & $\begin{array}{c}1=\text { strongly disagree, } \\
5=\text { strongly agree }\end{array}$ & $2.21(0.37)$ & $2.86(0.57)$ & $2.13(0.33)$ & .089 \\
\hline $\begin{array}{l}\text { How much influence do you have over } \\
\text { management decisions that affect your } \\
\text { practice? }\end{array}$ & $\begin{array}{l}1=\text { very little, } 5=\text { very } \\
\text { much }\end{array}$ & $2.72(0.39)$ & $4.64(0.49)$ & $2.32(0.36)$ & $<.001^{*}$ \\
\hline $\begin{array}{l}\text { How often are you able to match the amount of } \\
\text { time you have to spend with patients to the } \\
\text { level of complexity of each patient's case? }\end{array}$ & $1=$ never, $5=$ always & $3.29(0.28)$ & $4.62(0.25)$ & $3.03(0.24)$ & $<.001^{*}$ \\
\hline \multicolumn{6}{|l|}{ Outcomes } \\
\hline $\begin{array}{l}\text { How satisfied are you with your opportunities to } \\
\text { fully utilize your skills in your practice } \\
\text { situation? }\end{array}$ & $\begin{array}{l}1=\text { not satisfied, } 5=\text { very } \\
\text { satisfied }\end{array}$ & $3.55(0.36)$ & $4.38(0.44)$ & $3.58(0.3)$ & $.001^{*}$ \\
\hline How satisfied are you with being a physician? & $\begin{array}{l}1=\text { not satisfied, } 5=\text { very } \\
\text { satisfied }\end{array}$ & $4.00(0.36)$ & $4.00(0.53)$ & $4.39(0.25)$ & NS \\
\hline $\begin{array}{l}\text { Given your work situation in total, how would } \\
\text { you rate the overall quality of the medical care } \\
\text { you are able to provide? }\end{array}$ & $1=$ poor, $5=$ excellent & $4.21(0.18)$ & $4.68(0.27)$ & $4.26(0.2)$ & $.003^{*}$ \\
\hline $\begin{array}{l}\text { To what extent are you able to achieve your } \\
\text { overall professional goals within your current } \\
\text { practice situation? }\end{array}$ & $\begin{array}{l}1=\text { not at all, } 5=\text { very } \\
\text { much }\end{array}$ & $3.66(0.38)$ & $4.50(0.5)$ & $3.86(0.33)$ & $.001^{*}$ \\
\hline I plan to leave my practice in the near future. & $\begin{array}{c}1=\text { strongly disagree, } \\
5=\text { strongly agree }\end{array}$ & $2.66(0.54)$ & $1.52(0.42)$ & $2.50(0.39)$ & $.004^{*}$ \\
\hline
\end{tabular}

Data are shown as means (95\% confidence intervals) of Likert scale ratings. Bolded values indicate significant differences between micropractice and residency/community physicians.

*Values are significant at $P<.004$ (Kruskal-Wallis tests).

8 satisfaction and outcome items, deleting 1 item ("plan to leave workgroup in near future") because its addition lowered the overall internal consistency and reliability. The final 7-item scale had an internal reliability of $\alpha=0.77$ (acceptable). Parametric tests (analysis of variance and analysis of covariance) were used to analyze the composite score. Satisfaction measures were tested at a Bonferronicorrected $P=.004$.

\section{Results}

Response rates for the 3 groups varied: $56.94 \%$ of RPs, $26.12 \%$ of CPs, and $52.38 \%$ of MPs. There were no statistically significant differences between practice models by sex, years since res- idency, and number of hours spent on patient care each week.

The 13 content questions and their responses are provided in Table 1 . Table 2 includes selected comments from the survey. Comments were included if they were understandable and appropriate to the section.

More MPs practiced in a rural setting (41\%), whereas CPs and RPs practiced in urban $34 \%$ and $48 \%$, respectively) or suburban (55\% and 33\% respectively) settings $(P=.031)$. RPs and CPs were more likely than MPs to provide inpatient care $(90 \%$ and $84 \%$ vs $14 \%$, respectively; $P<.001$ ) and practice obstetrics (68\% and $45 \%$ vs $9 \%$, respectively; $P<.001$ ). MPs were less likely than RPs and CPs to insert intrauterine 


\section{Work satisfaction}

Community physicians

Residency physicians

Micropractice physicians

\section{Practice issues \\ Community physicians:}

Residency physicians

Micropractice physicians

\section{Outcomes}

Community physicians

Residency physicians

Micropractice physicians
"I'm mainly dissatisfied by the disparity in pay between primary care and specialties; I would argue other specialties pay should be lowered/brought into line with primary care."

"The dissatisfaction with income arises because of the lack of valuing primary care relative to specialist medicine."

"Clinic is too big .... Would love to get back to a smaller footprint type of clinic."

"The perk of the larger group was having less call and less rounding. Both of these while nice, have distanced us from personalized healthcare-and I suspect job satisfaction."

"I get discouraged with all the uncompensated time-phone calls, dictations. I am often working from home or on my days off to complete these things."

"As far as the ability to provide continuity of care, I am not sure the teaching clinics could do a worse job of prioritizing this if they tried."

"Always battling the tension between clinical productivity and other rewarding aspects of academic practice (teaching, research, leadership)."

"The nature of being a residency educator is that continuity will be diffused, so I accept that."

"I would not trade this model for anything short of bankruptcy."

"Income aside ... I have never been as happy practicing medicine as I am now."

"Though I make enough money for me I feel that I deserve to make more money for the amount of work I put in."

"I am very satisfied with the ultra flexibility of my schedule."

"I don't enjoy my work as much as I could if I were to have more time to learn and teach patients. The standard clinic template does not allow for much flex time to address more complicated issues 'on the spot'; this is the difficulty of trying to be 'efficient' while trying to be 'thorough'."

"Insurance continues to be a major challenge to offering appropriate care."

"Always a struggle with the schedule. [The] 99214 level often does not reflect the time needed for complex chronic disease management, especially in the elderly."

"I am not able to perform some of the procedures I previously was able to perform-colposcopy, flexible sigmoidoscopy, for example. I cannot afford this equipment, would not have the numbers to support their purchase, do not have staff to assist, do not have the room for it."

"I take all the time needed to see the patient, know about them and their family. It is very rewarding this type of practice."

"Haven't been able to do as much minor surgery without an assistant but plan to do more when I hire an MA."

'I am hopeful, and optimistic, that changes ... in regard to pay and adjustment in the model of compensation ... will more accurately reflect the work we do in patient panel management. If this change does not occur, it will make me more inclined to seek out jobs with less time constraint, which are paid for the work done."

"[My] confidence in the organization's ability to respond to market changes and commit resources to primary care and family medicine is at [an] all time low."

"I feel pressure to produce, to reach protocol standards, to have patients be 'very satisfied' with my care ... all while needing to be scholarly. It doesn't feel like I am left with any time to think deeply about anything."

"I do not feel compensation based on RVU production encourages me to practice my style of primary care medicine; I would prefer a salary model with incentives for providing optimum evidence based medical care."

"I am satisfied with the work I do professionally but I am not satisfied with the factors that impinge-low reimbursements and ceaseless demands for prior authorization."

MA, medical assistant; RVU, relative value units.

and Implanon devices or perform circumcisions, colposcopy, and casting ( $P<.05$ for all comparisons).

Years in current practice was considered a potential influence on other measures of satisfaction. We analyzed a subset of non-MPs consisting of only those with $\leq 10$ years in practice. Nearly the exact same pattern of results as those for physician satisfaction was seen as when using the full sample of physicians.

\section{Discussion}

Overall, MPs were more satisfied with their work, yet many found they had to supplement their in- 
come or take a significant pay cut. As primary care struggles to attract medical students and primary care physicians show higher levels of burnout than other specialties, ${ }^{6}$ applying concepts from a micropractice model that lead to higher physician satisfaction may make primary care more appealing and reduce burnout.

\section{Study Limitations}

This is a small study, with a low response rate, particularly from CPs. The RPs and CPs practice in a single system, limiting our sample population. In addition, there is no current research on physician satisfaction; most data are from the early 2000s, making comparisons difficult.

\section{Conclusions}

MPs found more satisfaction in their work at the cost of a decreased income and narrower scope of practice. We believe that these results are relevant to discussions pertaining to the provision of primary care, medical student recruitment, and physician burnout.

\section{References}

1. Freeborn DK. Satisfaction, commitment and psychological well-being among HMO physicians. West J Med 2001;174:13-8.

2. McKinlay JB, Marceau LD. The end of the golden age of doctoring. Int J Health Serv 2002;32:379-416.

3. Moore G, Wasson J. The ideal medical practice model: improving efficiency, quality and the doctor-patient relationship. Fam Pract Manag 2007;14:20-4.

4. Moore LG. Going solo: making the leap. Fam Pract Manag 2002;9:29-32.

5. Beasley J, Karsh B, Hagenaur M, Marchand L, Sainfort F. Quality of work life of independent vs employed family physicians in wisconsin: a WReN study. Ann Fam Med 2005;3:500-6.

6. Shanafelt T, Boone S, Tan L, et al. Burnout and satisfaction with work-life balance among US physicians relative to the general US population. Arch Intern Med 2012;172:1377-85. 